\title{
Fundusze surowcowe na rynku inwestycji alternatywnych w Polsce
}

\author{
Agnieszka Moskal ${ }^{\star}$, Danuta Zawadzka**
}

\section{Wprowadzenie}

Niestabilność na globalnych rynkach finansowych w ostatnich latach przełożyła się na poszukiwanie przez część inwestorów inwestycji, które pozwolą na uniezależnienie osiąganych wyników od sytuacji na rynku kapitałowym. Jedną z takich możliwości stwarzają inwestycje alternatywne.

Za pierwsze inwestycje alternatywne uważa się powstanie funduszy hedge, które datuje się na lata 50. XX w. (Mikita, Pełka 2009, s. 18). W następnych latach pojawiły się kolejne formy alternatywne w stosunku do tradycyjnej alokacji kapitału. Dynamiczny rozwój rynku inwestycji alternatywnych przypada na przełom XX/XXI wieku i związany był m.in. z tzw. bańką internetową (ang. dot-com buble), czyli załamaniem na rynkach finansowych spowodowanym znacznymi spadkami cen spółek z branży IT. Niestabilność na światowych rynkach finansowych po 2007 roku (Mishkin 2011, s. 49-70) przyczyniła się do zwiększonego zainteresowania inwestorów alternatywnymi formami alokacji kapitału. Globalna wartość aktywów inwestycyjnych o charakterze alternatywnym charakteryzuje się stabilnym wzrostem. Jedną z kategorii inwestycji alternatywnych stanowią fundusze alternatywne, w skład których wchodzą między innymi fundusze surowcowe (Perez 2012, s. 56). Rynek surowców stanowi ciekawą opcję dla inwestorów, którzy poszukują aktywów dywersyfikujących ich portfele. Badania przeprowadzone przez B. Büyüksahin i M. Haigh wskazują, iż korelacja stóp zwrotu z inwestycji

* Anieszka Moskal, Politechnika Koszalińska, Wydział Nauk Ekonomicznych, Katedra Finansów, agnieszka.moskal@tu.koszalin.pl

** Danuta Zawadzka, Politechnika Koszalińska, Wydział Nauk Ekonomicznych, Katedra Finansów, danuta.zawadzka@tu.koszalin.pl 
w surowce $\mathrm{z}$ inwestycjami w akcje nie przekracza 0,3 . Tymczasem korelacja stóp zwrotu uzyskiwanych z inwestycji w akcje różnych spółek wynosi ok. 0,9 (Büyüksahin, Haigh, Robe 2010, s. 76-95). Dywersyfikacja portfela jest wyrazem chęci zabezpieczenia przed gwałtownymi wahaniami na rynkach finansowych.

Celem artykułu jest ukazanie obecnego stanu rynku funduszy surowcowych w Polsce oraz ocena ich efektywności. Cel ten osiągnięto poprzez analizę struktury rynku funduszy alternatywnych (w tym funduszy surowcowych), wyznaczenie stóp zwrotu $\mathrm{z}$ inwestycji $\mathrm{w}$ fundusze surowcowe w Polsce, a także zbadanie korelacji funduszy $\mathrm{z}$ tradycyjnym rynkiem oraz portfelami rynkowymi poszczególnych funduszy.

\section{Istota funduszy alternatywnych}

Fundusze alternatywne na polskim rynku finansowym mogą funkcjonować dzięki Ustawie o funduszach inwestycyjnych z dnia 27 maja 2004 roku (Perez 2012 , s. 149). Grupę funduszy alternatywnych można wyodrębnić poprzez porównanie kilku najistotniejszych cech charakterystycznych dla funduszy tradycyjnych i alternatywnych. Cechy te zestawiono w tabeli 1.

Tabela 1. Porównanie cech tradycyjnych i alternatywnych funduszy inwestycyjnych

\begin{tabular}{|l|l|l|}
\hline \multicolumn{1}{|c|}{ Cechy } & \multicolumn{1}{|c|}{$\begin{array}{c}\text { Tradycyjne fundusze } \\
\text { inwestycyjne }\end{array}$} & \multicolumn{1}{|c|}{$\begin{array}{c}\text { Alternatywne fundusze } \\
\text { inwestycyjne }\end{array}$} \\
\hline Polityka inwestycyjna & $\begin{array}{l}\text { Oparta na zasadzie dywersyfi- } \\
\text { kacji ryzyka (duża lub bardzo } \\
\text { duża dywersyfikacja). }\end{array}$ & $\begin{array}{l}\text { Oparta na zasadzie dywersy- } \\
\text { fikacji ryzyka (mała, średnia } \\
\text { lub duża dywersyfikacja). }\end{array}$ \\
\hline Główny cel działalności & $\begin{array}{l}\text { Relatywne stopy zwrotu prze- } \\
\text { wyższające średnią rynkową. }\end{array}$ & $\begin{array}{l}\text { Osiągnięcie jak najwyższych } \\
\text { stóp zwrotu. }\end{array}$ \\
\hline $\begin{array}{l}\text { Stopień ryzyka } \\
\text { inwestycyjnego }\end{array}$ & Od małego do dużego. & $\begin{array}{l}\text { Od bardzo małego do bardzo } \\
\text { dużego. }\end{array}$ \\
\hline Konstrukcja funduszy & Otwarte, mieszane, zamknięte. & Otwarte, zamknięte. \\
\hline Rodzaj inwestorów & $\begin{array}{l}\text { Głównie ze średnią lub wy- } \\
\text { soką awersją do ryzyka. } \\
\text { Zarówno drobni, jak i zamoż- } \\
\text { ni inwestorzy indywidualni, } \\
\text { rzadziej inwestorzy instytu- } \\
\text { cjonalni. }\end{array}$ & $\begin{array}{l}\text { Głównie z niską lub bardzo } \\
\text { niską awersją do ryzyka. } \\
\text { Zamożni inwestorzy indy- } \\
\text { widualni oraz inwestorzy } \\
\text { instytucjonalni. }\end{array}$ \\
\hline Bariery wejścia/wyjścia & Nie & Tak \\
\hline $\begin{array}{l}\text { Ustawodawstwo } \\
\text { o funduszach inwestycyjnych }\end{array}$ & Tak & Generalnie nie \\
\hline
\end{tabular}

Źródło: Perez 2011, s. 13. 
Do grupy funudszy alternatywnych zalicza się (Perez 2012, s. 55-56):

- fundusze private equity - inwestujące w udziały spółek na niepublicznym rynku kapitałowym;

- fundusze surowcowe - fundusze, które lokują swoje środki w instrumenty finansowe oparte na surowcach, towarach;

- fundusze funkcjonujące na rynkach wschodzących;

- fundusze hedgingowe oraz fundusze funduszy hedgingowych;

- fundusze nieruchomości;

- fundusze venture capital - inwestycje w udziały spółek we wczesnej fazie rozwoju;

- fundusze związane $\mathrm{z}$ inwestycjami emocjonalnymi - inwestujące w np. kamienie szlachetne, luksusowe alkohole, dzieła sztuki.

Strategia inwestycyjna funduszy alternatywnych obejmuje zarówno inwestycje w aktywa finansowe, jak i niefinansowe (Kościelniak 1998, 31-33). Ze względu na aktywny charakter przyjętych strategii inwestycyjnych fundusze alternatywne wyróżniają się niską korelacją z instrumentami tradycyjnymi. Strategie te są akceptowane głównie przez zamożnych inwestorów indywidualnych oraz inwestorów instytucjonalnych. Często uczestnictwo $\mathrm{w}$ funduszach alternatywnych wiąże się z wyższym niż w przypadku funduszy tradycyjnych poziomem minimalnej pierwszej wpłaty (Ostrowska 2014, s. 34-35).

Grupa funduszy alternatywnych nie jest jednolita. Pomimo cech wspólnych, między poszczególnymi typami funduszy alternatywnych występują pewne różnice. Przykładowo fundusze hedgingowe charakteryzują się nieskorelowanymi z rynkiem finansowym stopami zwrotu, z kolei fundusze private equity/venture capital odznaczają się stopami zwrotu wysoce skorelowanymi z tradycyjnym rynkiem finansowym (McCary 2004, s. 5-6). Również, porównując płynność funduszy hedgingowych i surowcowych, można wysnuć wniosek, iż fundusze surowcowe są bardziej płynne. Wynika to $\mathrm{z}$ faktu, że fundusze surowcowe funkcjonują na płynnych rynkach, na których stosunkowo łatwo można zbyć instrumenty (McCary 2004, s. 7).

\section{Fundusze surowcowe jako inwestycje alternatywne}

Surowce stanowią zróżnicowaną grupę. Wyróżnia się surowce szlachetne (złoto, srebro, platyna), surowce energetyczne (ropa naftowa, gaz ziemny, węgiel), metale przemysłowe (aluminium, miedź, pallad itp.), a także surowce rolne (pszenica, kukurydza, kakao itp.) (Mikita, Pełka 2009, s. 173). Podział na surowce szlachetne i przemysłowe nie jest jednoznaczny, gdyż złoto, a zwłaszcza srebro, są wykorzy- 
stywane również w przemyśle czy medycynie (Gierałtowska 2013, s. 91). R. Eller i Ch. Sagerer (Eller, Sagerer 2008, s. 681-711) zaproponowali bardziej szczegółową klasyfikację surowców na surowce twarde (hard commodities) i surowce miękkie (soft commodities). Dokładny podział przedstawiono na rysunku 1.

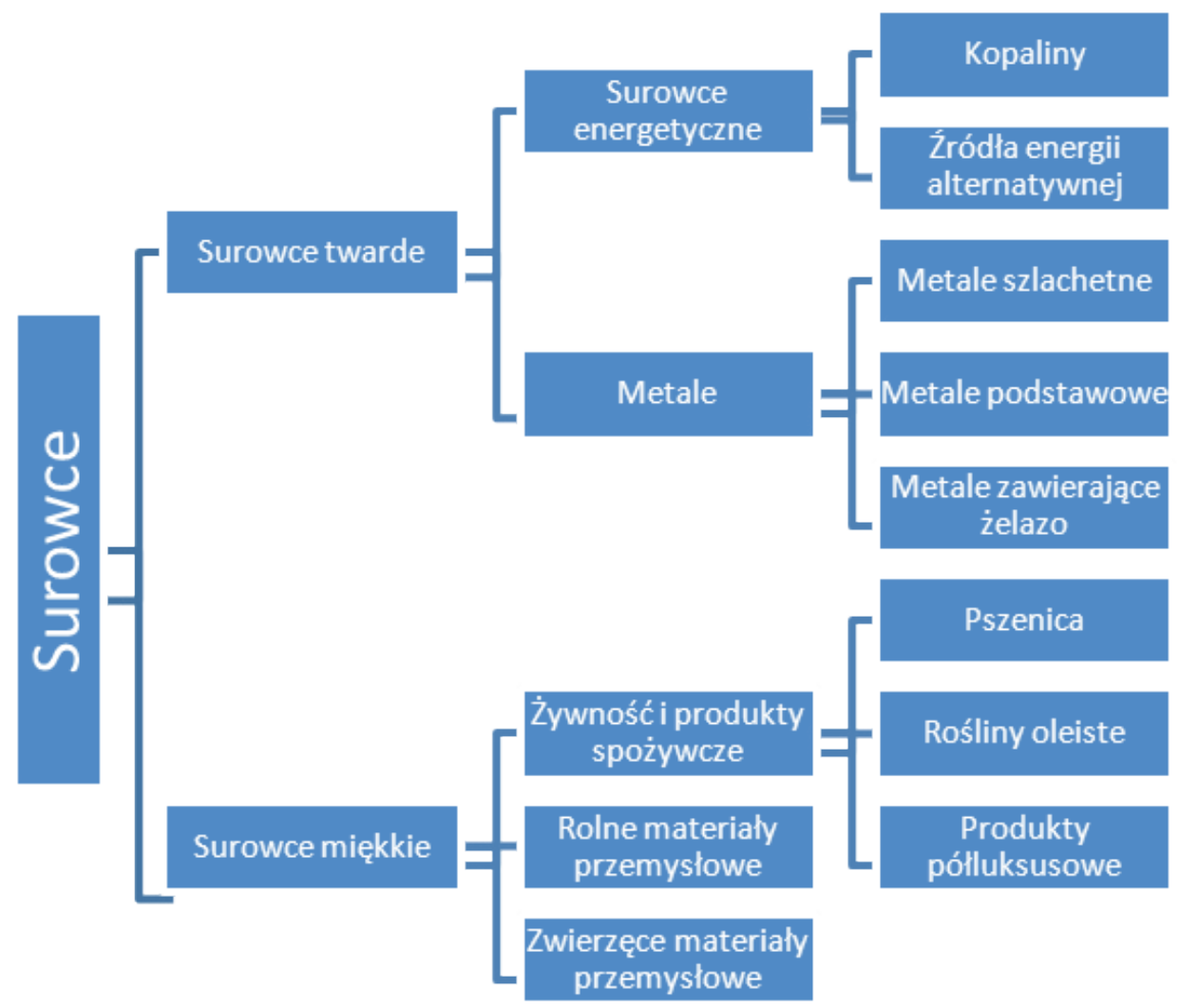

Rysunek 1. Klasyfikacja surowców

Źródto: Eller, Sagerer 2008, s. 682.

Inwestowanie w surowce może odbywać się w kilku wariantach (Fabozzi, Fuss 2008, s. 10):

1. Inwestycje bezpośrednie na rynku danego surowca;

2. Inwestycje pośrednie w akcje spółek surowcowych;

3. Fundusze surowcowe;

4. Instrumenty pochodne powiązane z surowcami (commodity futures);

5. Produkty strukturyzowane powiązane $\mathrm{z}$ indeksami surowcowymi futures (commodity futures indexes).

Rynek surowców zdominowany jest przez inwestorów instytucjonalnych (Krawiec 2012, s. 85). Jednakże inwestorzy indywidualni mają możliwość ulokowania kapitału na tym rynku poprzez fundusze surowcowe. Zaletami skorzystania $\mathrm{z}$ tej 
formy inwestycji są: dywersyfikacja portfela, profesjonalne zarządzanie portfelem, brak konieczności znajomości specyfiki rynku, a także niskie wymagania kapitałowe. Natomiast wadą są opłaty związane z przystąpieniem do funduszu inwestycyjnego. Inwestorzy indywidualni mogą wybierać między różnymi rodzajami funduszy surowcowych (Balarie 2007, s. 61): funduszami zasobów naturalnych (natural resourse funds), funduszami sektorowymi (sector specyfic mutual funds) oraz funduszami futures (commodity futures mutual funds). Polityka inwestycyjna pierwszych $z$ wymienionych funduszy skupia się na inwestycjach w akcje spółek związanych z produkcją oraz przetwarzaniem zasobów naturalnych. Fundusze sektorowe inwestują w daną grupę surowców, natomiast fundusze futures inwestują w instrumenty pochodne. Niejednokrotnie charakteryzują się zarządzaniem pasywnym, gdyż ich celem jest odwzorowywanie indeksów futures (commodity futures index).

\section{Metodyka badania i źródła danych}

W celu ukazania obecnego stanu rynku funduszy alternatywnych w Polsce podano wartości aktywów netto (WAN), będących w zarządzaniu tych funduszy na przestrzeni ostatnich ośmiu lat (od 2008 do 2015 roku). Wartości te uzyskano w wyniku analizy miesięcznych raportów Izby Zarządzających Funduszami i Aktywami (IZFA) ${ }^{1}$. Na polskim rynku finansowym zidentyfikowano 11 funduszy surowcowych. Jako podstawę włączenia funduszu do grupy funduszy surowcowych przyjęto definicję zaproponowaną przez IZFA, zgodnie z którą do funduszy surowcowych zalicza się te podmioty, które co najmniej 66\% wartości aktywów inwestują $\mathrm{w}$ instrumenty finansowe powiązane $\mathrm{z}$ rynkami surowców (np.: akcje spółek surowcowych lub towarowe instrumenty pochodne). W wyniku analizy informacji zawartych w prospektach emisyjnych oraz kartach funduszy dokonano charakterystyki funduszy surowcowych w Polsce. Zwrócono szczególną uwagę na rekomendowane wzorce (benchmarks), które pozwoliły na ocenę efektywności tych funduszy. Analiza składu portfela umożliwiła określenie stosowanej strategii inwestycyjnej. Rekomendowany horyzont inwestycyjny dla funduszy surowcowych wynosi od 3 do 5 lat, dlatego też wyznaczono historyczne stopy zwrotu $\mathrm{z}$ inwestycji w fundusze, w okresach od miesięcznego do pięcioletniego. Stopy zwrotu są powszechnie wykorzystywane do porównywania efektywności funduszy (Jajuga, Jajuga 2012, s. 93). Uzyskano 61 obserwacji miesięcznych stóp zwrotu od 31.12.2010 do 31.12.2015 roku. Zbadano również korelację wycen jednostek uczestnictwa/certyfikatów inwestycyjnych funduszy surowcowych $\mathrm{z}$ indeksami rynkowymi, gdyż brak powiązania jest jedną z najważniejszych cech inwestycji

1 http://www.izfa.pl (dostęp: 30.04.2016). 
o charakterze alternatywnym. W literaturze światowej możemy znaleźć wiele badań potwierdzających niską korelację inwestycji na rynku surowców (pośrednio bądź też bezpośrednio związanych z surowcami) z tradycyjnymi aktywami inwestycyjnymi oraz indeksami giełdowymi (patrz: Gorton, Rouwenhors 2006, s. 4768; Chong, Miffre 2006, s. 61-75).

\section{Wyniki i dyskusja}

Zmiany w globalnej wartości aktywów w latach 2005-2013, z wyszczególnieniem wielkości inwestycji tradycyjnych i inwestycji alternatywnych, przedstawiono na wykresie 1 . Zauważalny jest znaczący wzrost wartości aktywów lokowanych $\mathrm{w}$ inwestycje alternatywne po okresie największych spadków na rynkach finansowych w 2008 roku.

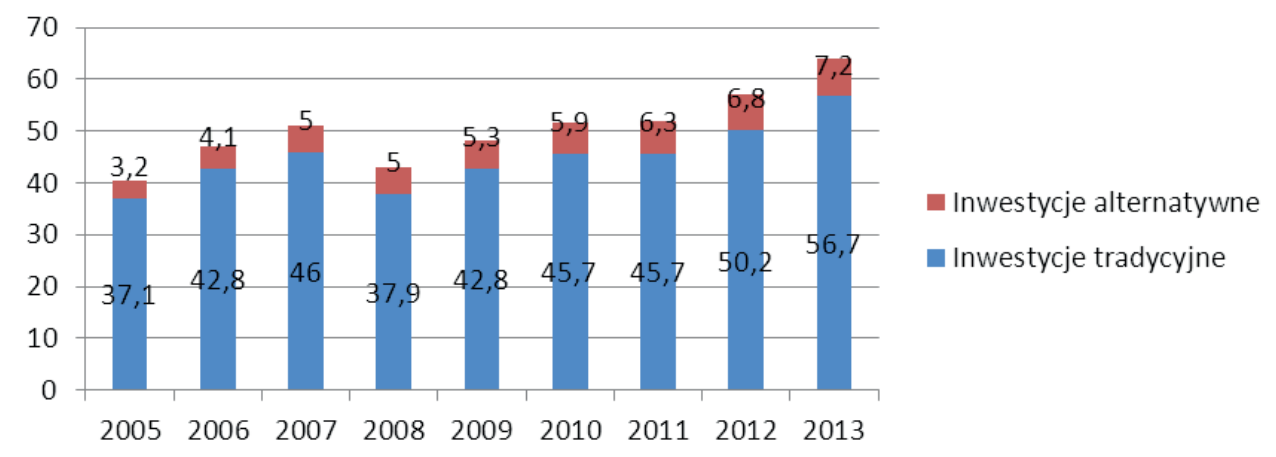

Wykres 1. Globalna wartość aktywów inwestycyjnych w latach 2005-2013 [w bln USD] Żródło: The Trillion-Dollar Convergence... 2014.

Na koniec grudnia 2013 roku wielkość aktywów ulokowanych w inwestycjach alternatywnych przekroczył 7,2 bln USD, co stanowiło blisko 12\% ogółu aktywów. Badania wykazują, iż już 10-20\% udział aktywów alternatywnych w portfelu inwestycyjnym przekłada się na znaczące obniżenie ryzyka oraz maksymalizację stóp zwrotu (Schneeweis, Karavas 2002). W związku z tym trend wzrostowy wartości inwestycji alternatywnych prawdopodobnie utrzyma się również w kolejnych latach.

Rynek funduszy alternatywnych w Polsce w ostatnich kilku latach odnotował dodatnią dynamikę zmian wartości aktywów netto. Wartości WAN głównych rodzajów funduszy alternatywnych na polskim rynku finansowym w latach 20082015 zaprezentowano w tabeli 2. 
Tabela 2. Zestawienie wartości aktywów netto wybranych funduszy alternatywnych na polskim rynku finansowym w latach 2008-2015 [w mln zt]

\begin{tabular}{|l|r|r|r|r|r|r|r|r|}
\cline { 2 - 9 } \multicolumn{1}{c|}{} & $\mathbf{2 0 0 8}$ & $\mathbf{2 0 0 9}$ & $\mathbf{2 0 1 0}$ & $\mathbf{2 0 1 1}$ & $\mathbf{2 0 1 2}$ & $\mathbf{2 0 1 3}$ & $\mathbf{2 0 1 4}$ & $\mathbf{2 0 1 5}$ \\
\hline Surowcowe & $\mathbf{4 6}$ & 118 & $\mathbf{2 8 8}$ & $\mathbf{4 4 8}$ & 519 & 249 & 324 & 449 \\
\hline Private equity & 4861 & 5503 & 11392 & 21501 & 23352 & 37176 & 39741 & 98041 \\
\hline Nieruchomości & 2523 & 2599 & 2633 & 3321 & 3486 & 2487 & 2131 & 1867 \\
\hline Sekurytyzacyjne & 850 & 924 & 728 & 1612 & 2071 & 1655 & 2638 & 5110 \\
\hline $\begin{array}{l}\text { Absolutnej stopy } \\
\text { zwrotu }\end{array}$ & - & - & - & 2948 & 4419 & 8579 & 8569 & 12127 \\
\hline $\begin{array}{l}\text { Suma wszystkich } \\
\text { krajowych funduszy } \\
\text { [w mld zt] }\end{array}$ & 73,67 & 93,5 & 115,6 & 114,37 & 145,82 & 188,94 & 208,93 & 252,17 \\
\hline
\end{tabular}

Źródło: opracowanie własne na podstawie raportów miesięcznych dotyczących wartości WAN przygotowanych przez IZFA.

W okresie od 2008 do 2015 roku wartość aktywów będących w posiadaniu zarządzających funduszami alternatywnymiwzrosła ponad 14-krotnie, do poziomu $117594 \mathrm{mln}$ zł. Z kolei udział aktywów funduszy alternatywnych w aktywach ogółem funduszy inwestycyjnych na koniec grudnia 2008 roku wynosił 11\%, natomiast w grudniu 2015 roku - ponad 46\%. Jednakże należy podkreślić, iż ze względu na niepubliczny charakter znacznej części funduszy trudno oszacować dokładną wartość aktywów netto funduszy alternatywnych.

$\mathrm{Na}$ polskim rynku fundusze surowcowe pojawiły się relatywnie późno, bo w 2008 roku. W grudniu 2015 roku na polskim rynku funkcjonowało 11 funduszy (subfunduszy), które zgodnie z przyjętą definicją IZFA można zaliczyć do funduszy surowcowych. Ich syntetyczną charakterystykę zaprezentowano w tabeli 3. $\mathrm{Z}$ punktu widzenia oceny efektywności funduszy surowcowych najistotniejszą cechę stanowi wykorzystywany wzorzec (benchmark). Określa on punkt odniesienia do porównywania różnych portfeli inwestycyjnych (Ostrowska 2014, s. 141). Benchmark uzależniony jest od stosowanej polityki inwestycyjnej i składu portfela inwestycyjnego.

Jak wynika $\mathrm{z}$ danych zawartych $\mathrm{w}$ tabeli 3, nie wszystkie fundusze surowcowe funkcjonują na podstawie wzorca odniesienia. Zarządzający funduszami bez określonego benchmarku skupiają się na uzyskiwaniu jak najwyższych absolutnych stóp zwrotu.

W tabeli 4 zestawiono stopy zwrotu krajowych funduszy surowcowych w latach 2011-2015. Minimalny rekomendowany okres inwestycji w fundusze surowcowe wynosi od 3 do 5 lat $^{2}$. W związku z tym za górny przedział czasowy historycznych stóp zwrotu przyjęto okres 60 miesięcy.

2 Na podstawie rekomendacji poszczególnych funduszy inwestycyjnych. 


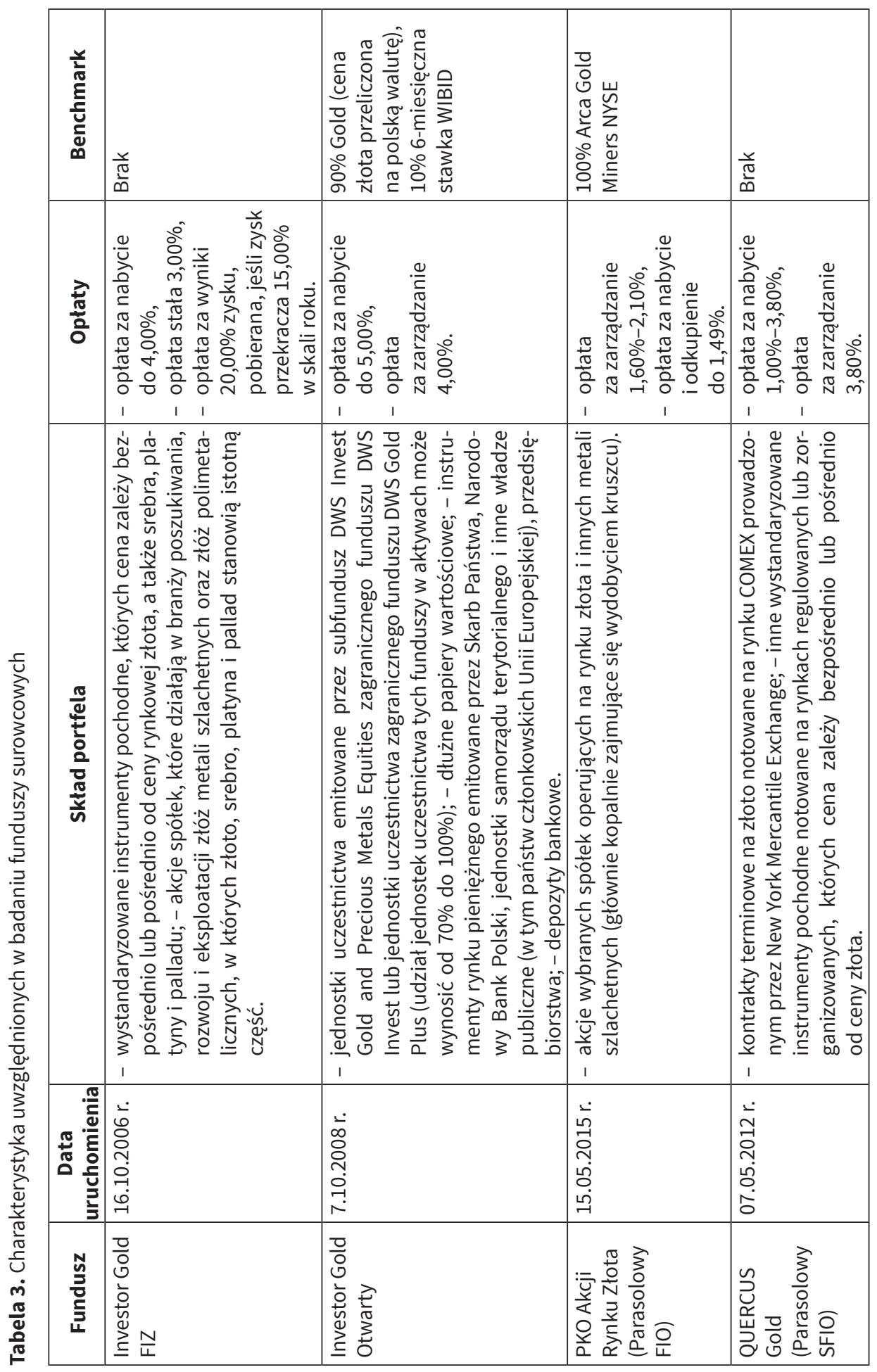




\begin{tabular}{|c|c|c|c|c|}
\hline$\frac{\text { ते }}{\frac{\pi}{0}}$ & 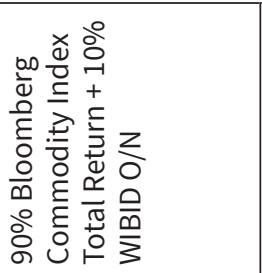 & 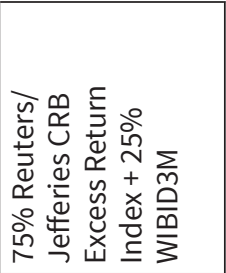 & $\frac{r}{\frac{\pi}{0}}$ & 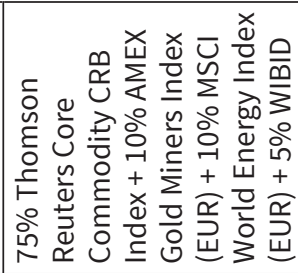 \\
\hline 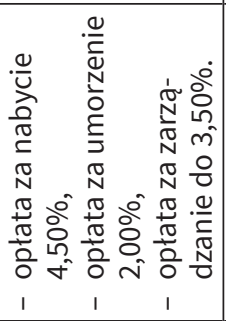 & 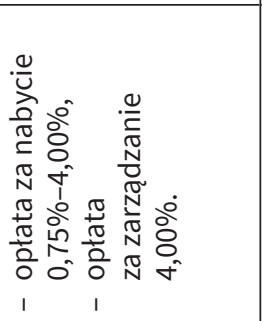 & 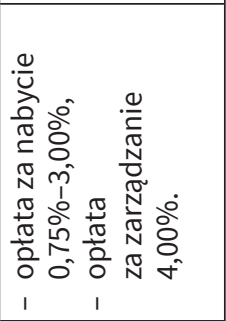 & 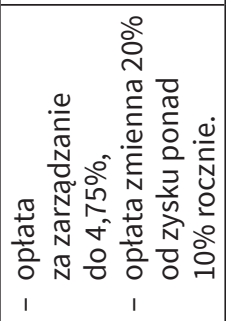 & 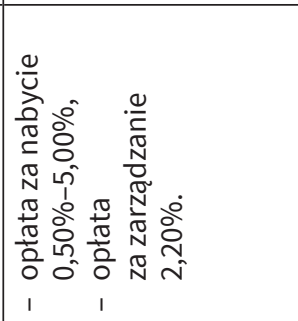 \\
\hline 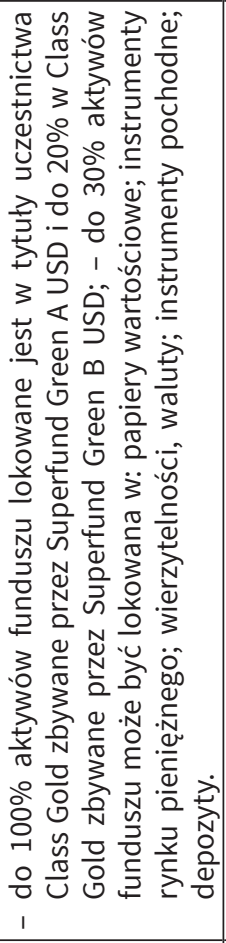 & 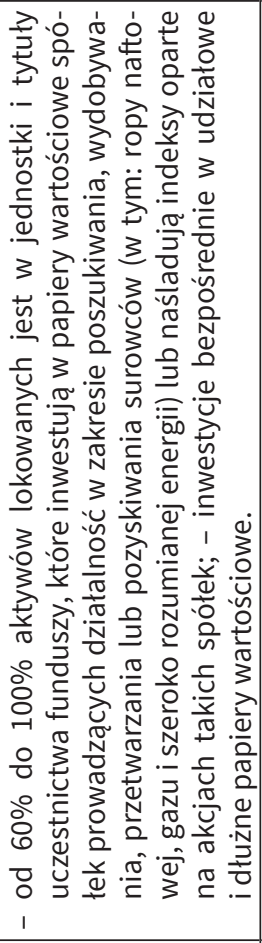 & 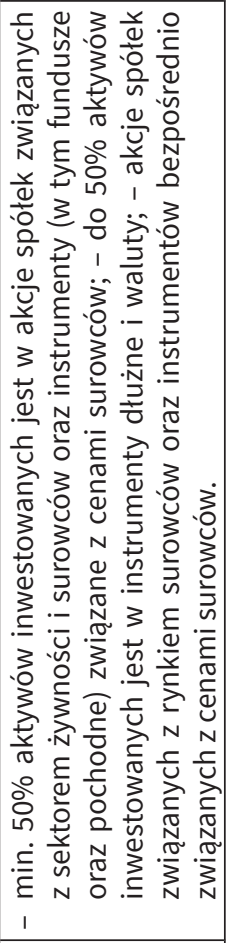 & 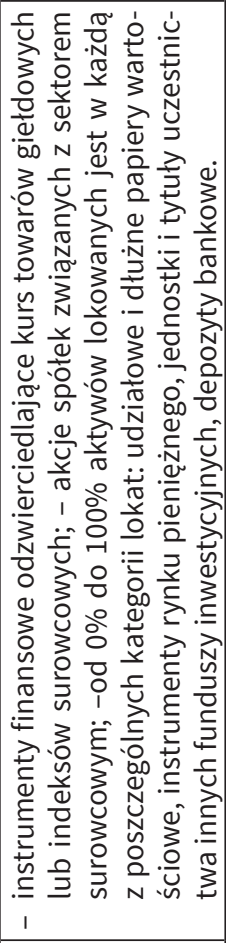 & 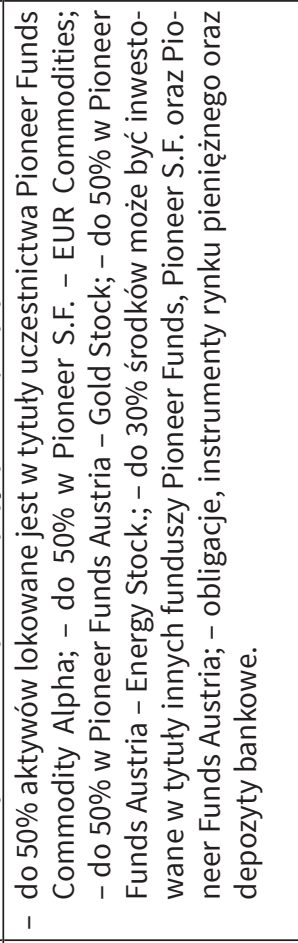 \\
\hline 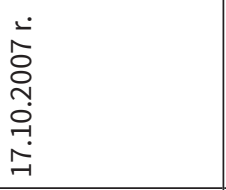 & 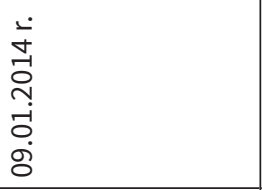 & 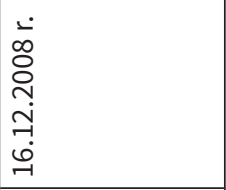 & 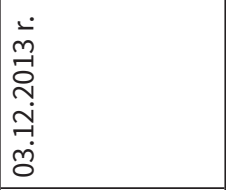 & 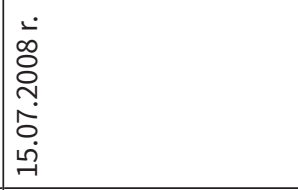 \\
\hline 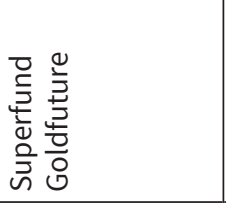 & 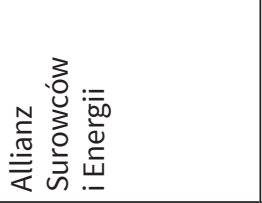 & 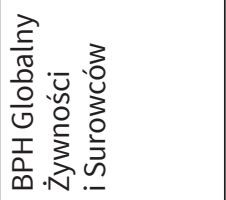 & 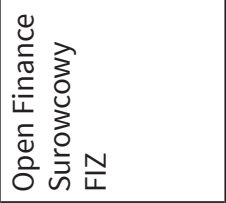 & 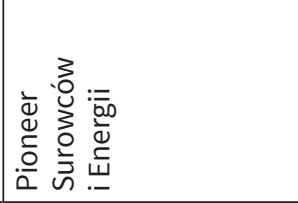 \\
\hline
\end{tabular}




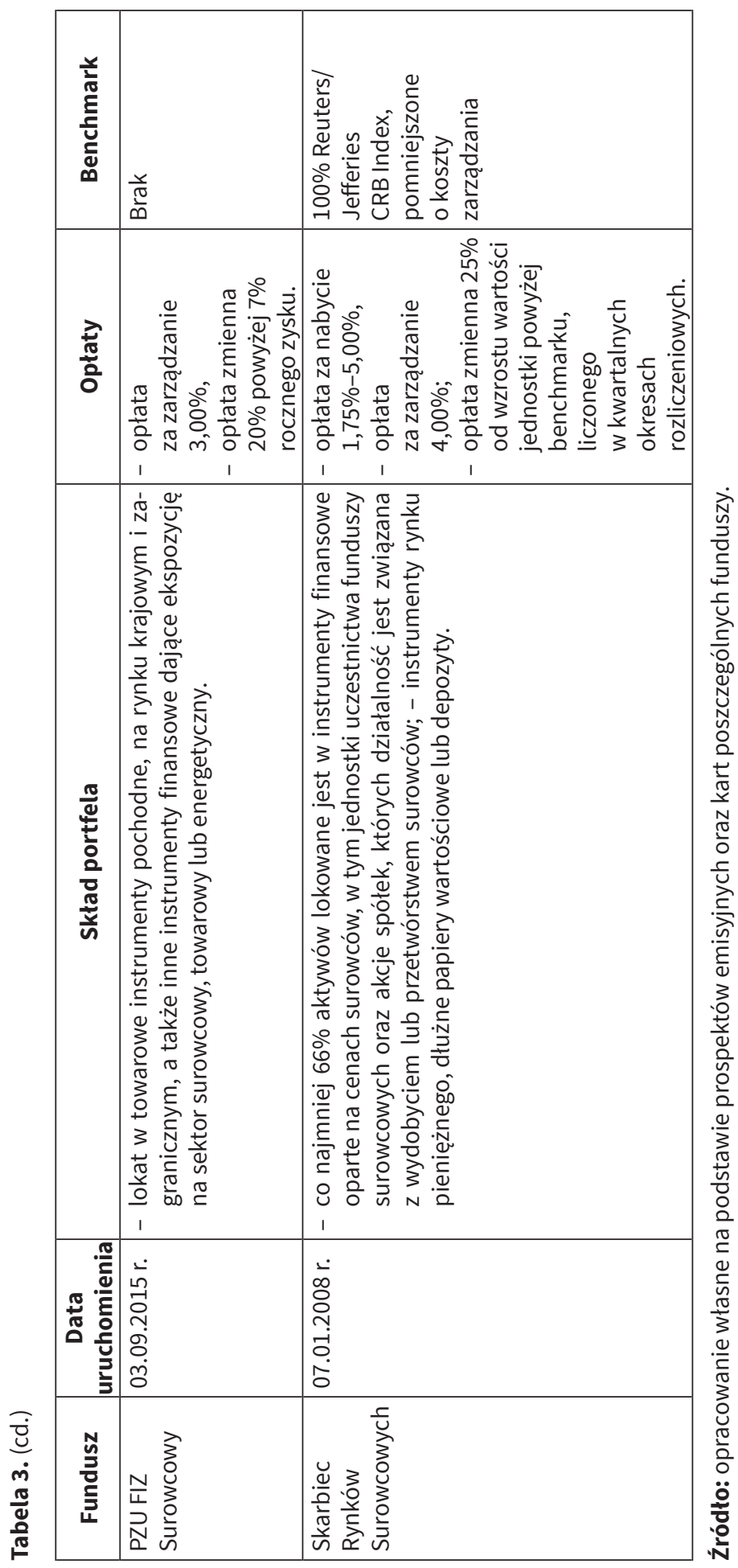




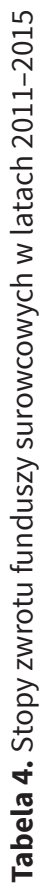
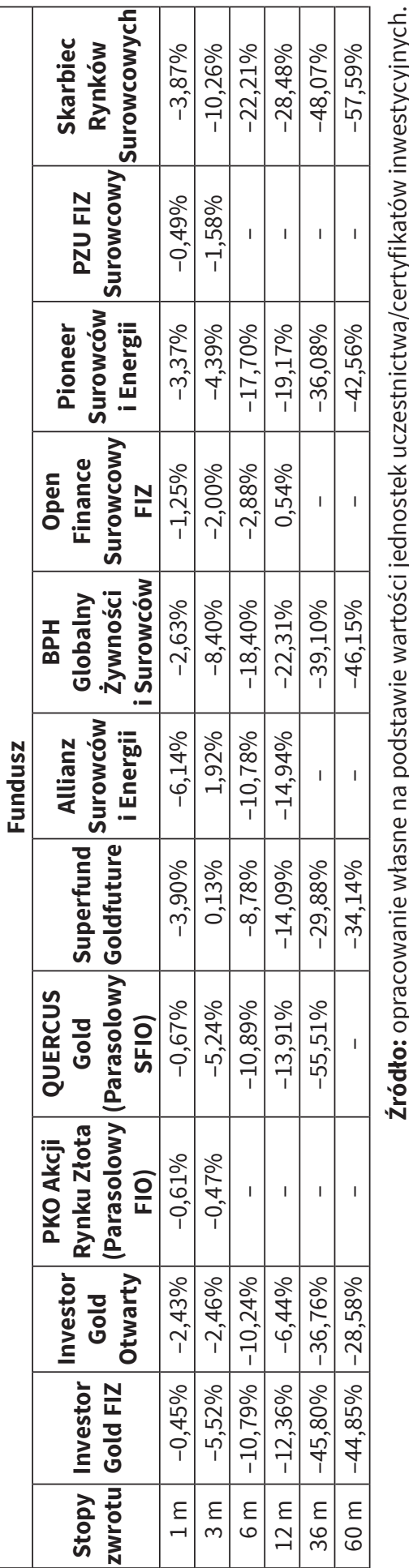

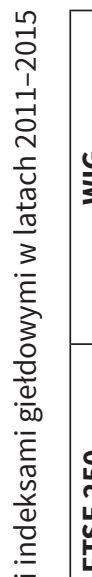

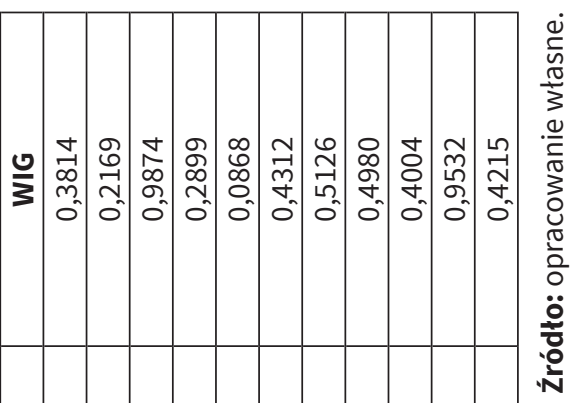

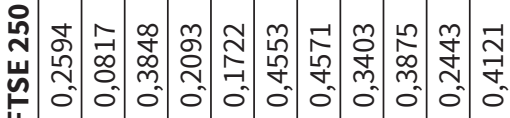

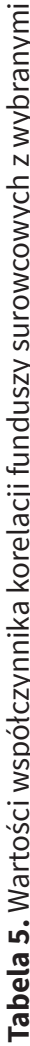

:

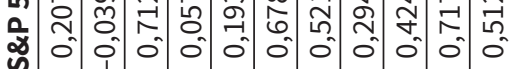

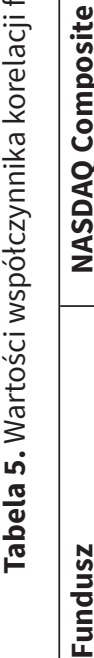

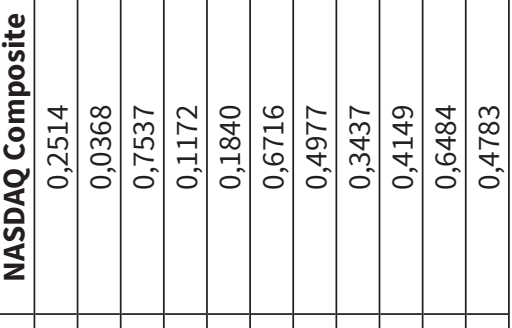

旁

은

을 $\frac{0}{4}$

3.

空

苟

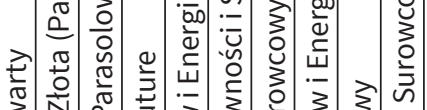

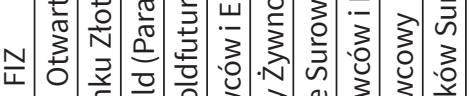

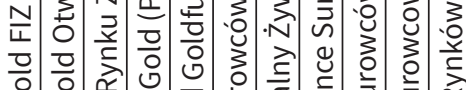

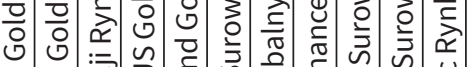
tᄒ 苞苞 主 
Ostatnie 5 lat nie było okresem sprzyjającym wysokim stopom zwrotu dla inwestujących $\mathrm{w}$ fundusze surowcowe. Żaden $\mathrm{z}$ funduszy bowiem nie wygenerował dodatnich stóp zwrotu powyżej rocznego horyzontu inwestycyjnego. Długoterminowe 5-letnie stopy zwrotu wahały się od $-57,59 \%$ (Skarbiec Rynków Surowcowych) do $-28,58 \%$ (Investor Gold Otwarty). Roczne stopy zwrotu znajdowały się w przedziale od $-28,48 \%$ (Skarbiec Rynków Surowcowych) do 0,54\% (Open Finance Surowcowy FIZ). Fundusze, które najkrócej funkcjonują na rynku (poniżej 1 roku), charakteryzują się relatywnie lepszymi wynikami inwestycyjnymi niż pozostałe fundusze. Najwyższe stopy zwrotu odnotowano w przypadku funduszu Allianz Surowców i Energii dla okresu 3 miesięcznego (1,92\%). Warto zauważyć, iż jest to jeden z funduszy, który funkcjonuje na rynku od mniej niż roku. Co ciekawe - ten sam fundusz charakteryzuje się zdecydowanie najniższą miesięczną (czyli najkrótszą z uwzględnionych) stopą zwrotu na poziomie $-6,14 \%$. Ujemne stopy zwrotu znajdują uzasadnienie w sytuacji na rynkach surowców, które znajdują się w portfelach inwestycyjnych funduszy. W ostatnich 5 latach cena za uncję złota obniżyła się o ponad $20 \%$, a srebra o $50 \%^{3}$.

Fundusze surowcowe są przykładem funduszy alternatywnych, toteż z definicji nie powinny być skorelowane $\mathrm{z}$ rynkiem tradycyjnym. W tabeli 5 przedstawiono wartości współczynnika korelacji między poszczególnymi funduszami i wybranymi indeksami giełdowymi w latach 2011-2015. Indeksy giełdowe wybrano na podstawie analizy wskazanego w kartach funduszy składu portfela inwestycyjnego.

Zgodnie z oczekiwaniami odnotowano wartości współczynnika korelacji na bardzo niskim poziomie. Jedyny wyjątek stanowi bardzo silna dodatnia korelacja PKO Akcji Rynku Złota oraz PZU FIZ Surowcowy z szerokim indeksem WIG - odpowiednio 0,9874 i 0,9532. W przypadku PKO Akcji Rynku Złota tak wysokie skorelowanie z rynkiem kapitałowym wynika z polityki inwestycyjnej. Aktywa funduszu inwestowane są przede wszystkim w akcje kopalni, które zajmują się wydobyciem kruszcu. Natomiast PZU FIZ Surowcowy inwestuje głównie $\mathrm{w}$ towarowe instrumenty pochodne i inne instrumenty finansowe. Bardzo wysoka replikacja WIG wynika z ekspozycji na sektor energetyczny oraz znacznego udziału inwestycji na krajowym rynku.

W tabeli 6 zestawiono wartości współczynnika korelacji między funduszami surowcowymi a indeksami, które stanowią dla nich benchmark.

Tabela 6. Korelacja funduszy surowcowych z benchmarkami w latach 2011-2015

\begin{tabular}{|c|c|c|c|c|c|c|}
\hline Fundusz & $\begin{array}{c}\text { Investor } \\
\text { Gold } \\
\text { Otwarty }\end{array}$ & $\begin{array}{c}\text { PKO Akcji } \\
\text { Rynku Ztota } \\
\text { (Parasolowy } \\
\text { FIO) }\end{array}$ & $\begin{array}{c}\text { Allianz } \\
\text { Surowców } \\
\text { i Energii }\end{array}$ & $\begin{array}{c}\text { BPH } \\
\text { Globalny } \\
\text { Żywności } \\
\text { i Surowców }\end{array}$ & $\begin{array}{c}\text { Pioneer } \\
\text { Surowców } \\
\text { i Energii }\end{array}$ & $\begin{array}{c}\text { Skarbiec } \\
\text { Rynków } \\
\text { Surowcowych }\end{array}$ \\
\hline Benchmark $^{*}$ & 0,968336 & 0,990428 & 0,796412 & 0,920729 & 0,572422 & 0,910223 \\
\hline
\end{tabular}

*Zgodnie z tabelą 3.

Źródło: opracowanie własne.

3 Obliczenia własne na podstawie cen złota i srebra pozyskanych z historycznych wycen dostępnych na portalu http://www.stooq.pl. 
$\mathrm{Z}$ analizowanych 11 funduszy tylko w odniesieniu do 6 funduszy określony był wzorzec. W przypadku PKO Akcji Rynku Złota i Investor Gold Otwarty możemy zauważyć silną replikację indeksu - współczynniki korelacji wynoszą odpowiednio 0,990428 i 0,968336. Oba fundusze prowadzą politykę inwestycyjną, której podstawę stanowią pośrednie inwestycje w złoto. Bardzo wysokie współczynniki korelacji zauważalne są dla BPH Globalny Żywności i Surowców oraz Skarbiec Rynków Surowcowych - 0,920729 i 0,910223. Natomiast najsłabiej skorelowany z portfelem wzorcowym jest Pioneer Surowców i Energii, dla którego współczynnik korelacji wynosi 0,572422 .

Tabela 7. Stopy zwrotu benchmarków w latach 2011-2015

\begin{tabular}{|c|c|c|c|c|c|c|}
\hline 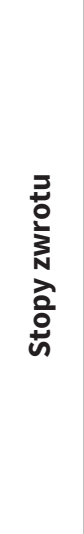 & 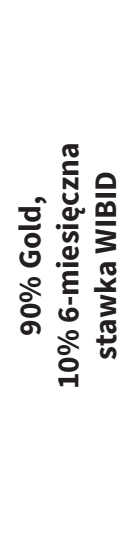 & 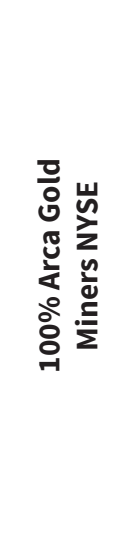 & 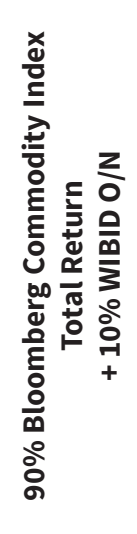 & 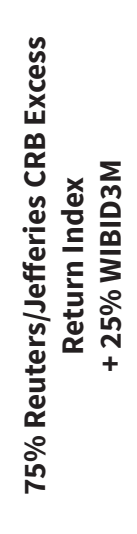 & 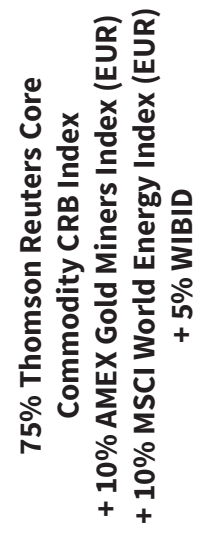 & 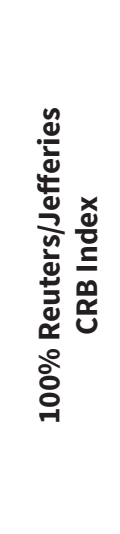 \\
\hline $1 \mathrm{~m}$ & $-0,30 \%$ & $0,84 \%$ & $-3,08 \%$ & $-6,66 \%$ & $-5,58 \%$ & $-6,68 \%$ \\
\hline $3 \mathrm{~m}$ & $-7,07 \%$ & $-7,80 \%$ & $-10,12 \%$ & $-5,78 \%$ & $-6,72 \%$ & $-5,79 \%$ \\
\hline $6 \mathrm{~m}$ & $-3,08 \%$ & $0,19 \%$ & $-14,37 \%$ & $-9,86 \%$ & $-8,53 \%$ & $-9,89 \%$ \\
\hline $12 \mathrm{~m}$ & $-10,27 \%$ & $-25,52 \%$ & $-24,66 \%$ & $-16,59 \%$ & $-19,34 \%$ & $-16,59 \%$ \\
\hline $36 \mathrm{~m}$ & $-36,69 \%$ & $-70,38 \%$ & $-43,43 \%$ & $-38,23 \%$ & $-21,35 \%$ & $-38,12 \%$ \\
\hline $60 \mathrm{~m}$ & $-20,38 \%$ & $-74,51 \%$ & $-51,96 \%$ & $-46,59 \%$ & $-31,63 \%$ & $-46,54 \%$ \\
\hline
\end{tabular}

Źródto: opracowanie własne.

W celu porównania efektywności uzyskiwanych przez fundusze surowcowe wyników z portfelem wzorcowym wyznaczono ich stopy zwrotu. Wyniki zestawiono w tabeli 7. Stopy zwrotu uzyskiwane z inwestycji w fundusz Investor Gold Otwarty były wyższe niż benchmark w przypadku 3-miesięcznego oraz rocznego horyzontu inwestycji. Natomiast Allianz Surowców i Energii uzyskał niższe stopy zwrotu niż wzorzec jedynie w najkrótszym (miesięcznym) okresie inwestycji. BPH Globalny Żywności i Surowców wygenerował wyższe stopy zwrotu niż benchmark jedynie w dwóch okresach - miesięcznym i 5-letnim, choć w przypadku 60-miesięcznej stopy zwrotu różnica pomiędzy funduszem a benchmarkiem wyniosła zaledwie 0,4 punktu procentowego. Krótkookresowe (horyzont czasowy wynoszący miesiąc, 3 miesiące i rok) inwestycje w Pioneer Surowców i Energii okazały się bardziej 
dochodowe niż w przypadku wzorca. W przypadku funduszu Skarbiec Rynków Surowcowych jedynie stopy zwrotu uzyskane w okresie miesięcznym były wyższe niż w odniesieniu do portfela wzorcowego. Wyniki stóp zwrotu dla benchmarków są wyższe niż dla funduszy surowcowych w przypadku 3-letnich i 5-letnich okresów inwestycyjnych, co wskazuje na niską efektywność funduszy surowcowych w Polsce.

\section{Podsumowanie}

Inwestycje alternatywne zyskują coraz większe zainteresowanie ze strony inwestorów - zarówno instytucjonalnych, jak i indywidualnych. Stanowią one ciekawą i jednocześnie różnorodną opcję lokowania środków. Polski rynek funduszy surowcowych wciąż znajduje się w początkowej fazie rozwoju. Wyniki tych funduszy w dużej mierze uzależnione są od zmiany cen surowców oraz zmiany cen akcji spółek związanych z wydobyciem i przetwarzaniem surowców. Alternatywny charakter inwestycji w fundusze surowcowe znajduje swoje odzwierciedlenie w niskich współczynnikach korelacji z indeksami rynkowymi. Ostatnie 5 lat inwestycji w fundusze surowcowe odznaczało się uzyskiwaniem ujemnych stóp zwrotu. Jest to skutek znacznych spadków cen surowców, które mają istotny udział w portfelach inwestycyjnych poszczególnych funduszy. Porównując stopy zwrotu z portfeli rynkowych, można wskazać na niską efektywność inwestycji w fundusze surowcowe. Mimo niekorzystnych wyników funduszy surowcowych w latach 2011-2015 na rynku pojawiają się nowe fundusze inwestujące zarówno pośrednio, jak i bezpośrednio na rynku surowców. Wzrasta również wartość aktywów netto, będąca w zarządzaniu funduszy surowcowych. Stabilizacja na rynku surowców oraz wykorzystywanie nowatorskich strategii inwestycyjnych powinno okazać się kluczowe dla przyszłości tej grupy funduszy w Polsce.

\section{Bibliografia}

Balarie E. (2007), Commodities for Every Portfolio, John Wiley \& Sons, Hoboken, New Jersey.

Büyüksahin B., Haigh M., Robe M. (2010), Commodities and Equities: Ever a "Market of One"?, Journal of Alternative Investments nr 12, p. 76-95.

Chong J., Miffre J. (2006), Conditional Correlation and Volatility in Commodity Futures and Traditional Asset Markets, Journal of Alternative Investments, Vol. 12, No. 3, p. 61-75.

Eller R., Sagerer Ch. (2008), An Overview of Commodity Sectors, [in:] F.J. Fabozzi, R. Fuss, D.G. Kaiser, The Handbook of Commodity Investing, John Wiley \& Sons, Hoboken, New Jersey. 
Fabozzi F.J., Fuss R. (2008), A Primer on Commodity Investing, [in:] F.J. Fabozzi, R. Fuss, D.G. Kaiser, The Handbook of Commodity Investing, John Wiley \& Sons, Hoboken, New Jersey.

Gierałtowska U. (2013), Inwestowanie w metale szlachetne jako alternatywna forma lokowania kapitału, Prace Naukowe Uniwersytetu Ekonomicznego we Wrocławiu, nr 323.

Gorton G., Rouwenhorst K.G. (2006), Facts and Fantasies about Commodity Futures, Financial Analysts Journal, Vol. 62, No. 2, p. 47-68.

Jajuga K., Jajuga T. (2012), Inwestycje. Instrumenty finansowe, aktywa niefinansowe, ryzyko finansowe, inżynieria finansowa, Wydawnictwo Naukowe PWN, Warszawa.

Kościelniak G. (1998), Fundusze powiernicze, Zakamycze, Kraków.

Krawiec M. (2012), Testing the Granger casuality for commodity mutual funds in Poland and commodity prices, Quantitave Methods in Economics, XIII-2.

McCary S.A. (2004), Hedge Fund Course, New York.

Mikita M., Pełka W. (2009), Rynki inwestycji alternatywnych, Poltext, Warszawa.

Mishkin F. (2011), Over the Cliff: From the Subprime to the Global Financial Crisis, Journal of Economic Perspectives, Vol. 25, No. 1, Winter 2011, p. 49-70.

Ostrowska E. (2014), Portfel inwestycyjny klasyczny i alternatywny, C.H. Beck, Warszawa.

Perez K. (2011), Fundusze hedge. Istota, strategie i potencjał rynku, Wydawnictwo C.H. Beck, Warszawa.

Perez K. (2012), Fundusze inwestycyjne. Rodzaje, zasady funkcjonowania, efektywność, Wolters Kluwer, Warszawa.

Schneeweis T., Karavas V.N., Georgiev G. (2002), Alternative Investments in the Institutional Portfolio, AIMA.

The Trillion-Dollar Convergence: Capturing the Next Wave of Growth in Alternative Investments (2014), McKinsey\&Company, http://dailyalts.com/wp-content/uploads/2014/08/McKinsey-Company_2014_Capturing-the-Next-Wave-of-Growth-in-Alternative....pdf (dostęp: 20.04.2016).

\section{FUNDUSZE SUROWCOWE NA RYNKU INWESTYCJI ALTERNATYWNYCH W POLSCE}

\section{Streszczenie}

Celem artykułu jest określenie obecnego stanu rynku funduszy surowcowych w Polsce oraz ocena ich efektywności. Cel ten osiągnięto poprzez analizę struktury rynku funduszy alternatywnych ( $w$ tym funduszy surowcowych), wyznaczenie stóp zwrotu $\mathrm{z}$ inwestycji w fundusze surowcowe w Polsce, a także zbadanie korelacji funduszy z tradycyjnym rynkiem oraz portfelami rynkowymi poszczególnych funduszy. Alternatywny charakter inwestycji w fundusze surowcowe znajduje swoje odzwierciedlenie w niskich współczynnikach korelacji z indeksami rynkowymi. Ostatnie 5 lat inwestycji w fundusze surowcowe odznaczało się uzyskiwaniem ujemnych stóp zwrotu. Jest to skutek znacznych spadków cen surowców, które mają istotny udział w portfelach inwestycyjnych poszczególnych funduszy. Mimo niekorzystnych wyników funduszy surowcowych w latach 2011-2015 na rynku pojawiają się nowe fundusze inwestujące zarówno pośrednio, jak i bezpośrednio na rynku surowców. Wzrasta również wartość aktywów netto, będąca w zarządzaniu funduszy surowcowych. Stabilizacja na rynku surowców i wykorzystywanie nowatorskich strategii inwestycyjnych powinno okazać się kluczowe dla przyszłości tej grupy funduszy w Polsce.

Słowa kluczowe: inwestycje alternatywne, fundusze surowcowe, benchmark, efektywność 


\section{COMMODITY FUNDS IN THE MARKET OF ALTERNATIVE INVESTMENTS IN POLAND}

\section{Summary}

The aim of the paper to identify the current state of the market commodity funds in Poland and assessment of their effectiveness. This object is achieved by analyzing the structure of the market of alternative funds (including commodity funds), setting rates of return on investments in the commodity funds in Poland, and to investigate the correlation of funds from the traditional market and the market portfolio of individual funds. The alternative nature of investments in commodity funds is reflected in the low coefficients of correlation with market indexes. The last 5 years of investment in commodity funds was characterized by obtaining negative returns. This is a result of significant declines in commodity prices, which have a significant share in the investment portfolios of individual funds. Despite the negative results of commodity funds in 2011-2015 in the market, there are new funds investing indirectly as well as directly on the raw materials market. Net asset value, which is in managing commodity funds is increasing. The stabilization of the market of raw materials and use of innovative investment strategies should prove crucial for the future of this group of funds in Poland.

Keywords: alternative investments, commodity funds, benchmark, effectiveness 